\title{
熱可塑性樹脂の粘弾粘塑性特性評価と有限要素解析
}

\author{
高岡 治輝*1, 坂上 賢一*2
}

(2019 年 2 月 26 日受付)

\section{Evaluation of Viscoelastic-Viscoplastic Characteristics and Finite Element Analyses for Thermoplastics}

\author{
Haruki TAKAOKA*1 and Kenichi SAKAUE*2
}

(Received February 26, 2019)

\begin{abstract}
Thermoplastics are viscoelastic-viscoplastic materials whose mechanical behavior depends on temperature and strain rate. In this study, the viscoelastic-viscoplastic characteristics of polybutylene terephthalate are evaluated on the basis of the mechanical model consisting of Schapery nonlinear viscoelasticity and Perzyna viscoplasticity. Also, the viscoelastic-viscoplastic behavior of the polybutylene terephthalate is predicted by finite element simulation. The evaluation reveals that the initial yield stress depends on temperature and strain rate; however, viscosity depends on only strain rate. Furthermore, the rate sensitivity is independent of temperature and strain rate. The finite element simulation using identified viscoelastic-viscoplastic characteristics can reproduce the stress-strain relationship in the uniaxial tensile tests under various testing conditions. It is expected that the time-temperature superposition principle can be applied to not only the maximum stress but also the initial yield stress.
\end{abstract}

Key words: Viscoelasticity, Viscoplasticity, Thermoplastics, Finite element analysis, Material testing

\section{1. 緒 \\ 言}

繊維強化熱可塑性樹脂（FRTP）は軽量性や優れた成 形性の観点から，熱硬化性樹脂をマトリクスとする複合 材料の代替として研究開発が盛んに行われている。しか し，母材である熱可塑性樹脂は，降伏応力以下ではひず み回復可能な粘弾性挙動, 降伏応力以上ではひずみ回復 不可能な粘塑性挙動を示し, 変形の全過程で温度とひず み速度依存性が顕著な粘弾粘塑性材料である。そのた め, FRTP も母材に依存した粘弾粘塑性特性を示す。し たがって,マルチスケール解析など用いて FRTP の力学

*1 芝浦工業大学大学院理工学研究科機械工学専攻 大 学院生（135-8548 東京都江東区豊洲 3-7-5)

Graduate Student, Department of Mechanical Engineering, Graduate School of Engineering and Science, Shibaura Institute of Technology

*2 芝浦工業大学工学部機械工学科 准教授

Associate Professor, Department of Mechanical Engineering, Faculty of Engineering, Shibaura Institute of Technology
挙動を予測するためには, 熱可塑性樹脂の粘弾粘塑性特 性の計測と力学モデルが不可欠である.

粘弾粘塑性体の力学モデルに関する既存の研究では, 粘弾性体と粘塑性体の直列モデルを用いたものが多い. 粘弾性体のモデルには線形粘弾性体や Schapery 非線形 粘弾性体 ${ }^{1,2}$ が多く用いられている。粘塑性体の力学モ デルに関しては文献 3）にまとめられているように数多 くの発展則モデルが提案されているが，熱可塑性樹脂の 粘塑性体にはPerzyna 粘塑性体 4 (,5) 用いた研究が多 い. また, 既存の研究では力学モデルの提案に加え, 汎 用有限要素解析ソフトに力学モデルを実装し, シミュレ ーションを行うための数值解析アルゴリズムも検討され ている ${ }^{6}$. Kim らは，高密度ポリエチレンのクリープリ カバリー挙動を Schapery 非線形粘弾性体と Perzyna 粘塑性体によりモデル化し, 反復法による数值解析アル ゴリズムを提案している ${ }^{7,8)}$. Tscharnuter らは, ポリプ ロピレンの複数のひずみ入力における応力緩和挙動を Schapery 非線形粘弾性体と Perzyna 粘塑性体によりモ デル化し，実験を再現できることを示している9. 
一方, 粘弾粘塑性特性の計測と力学モデルに関して は，著しい温度とひずみ速度依存性のために，複数の温 度条件やひずみ速度条件における材料試験が必要であ る. Abu Al-Rubらは，ポリメタクリル酸メチル樹脂の クリープリカバリー挙動を Schapery 非線形粘弾性体, Perzyna 粘塑性体，粘性損傷でモデル化し，評価した材 料定数を温度の関数として表現している. その結果, 複 数の温度での力学挙動を再現できることが示されてい る。しかし, 温度依存性の妥当性については議論がされ ていない ${ }^{10,11)}$. Drozdov は, 熱力学的定式化に基づいた 粘弾粘塑性モデルを用い，ポリプロピレンの単軸引張に おける最大応力と粘塑性材料定数の温度依存性やひずみ 速度依存性を議論している．最大応力は時間-温度換算 則が成立しているが，粘塑性材料定数は一貫性のある温 度依存性やひずみ速度依存性が現れていないことを示し ている ${ }^{12)}$.これらの研究は粘塑性特性の温度依存性やひ ずみ速度依存性を検討している数少ない研究であり, 熱 可塑性樹脂の粘塑性特性の温度依存性やひずみ速度依存 性は完全には理解されていない。

本研究では, ポリブチレンテレフタレート (PBT) 樹 脂の力学挙動を Schapery 非線形粘弾性体と Perzyna 粘塑性体でモデル化し，その力学特性を計測する。一般 に, Schapery 非線形粘弾性体を含む粘弾粘塑性体の力学 特性計測ではクリープリカバリー試験が行われる ${ }^{13 \sim 15)}$. しかし,クリープリカバリー試験で温度依存性を明らか にするためには温度と応力を変えて試験を繰り返し実施 する必要があり，多大なコストを要する，また，ひずみ 速度依存性をクリープリカバリー試験で明らかにするの は困難である。そこで, 本研究では, 動的粘弾性試験と 単軸引張試験から粘弾性特性と粘塑性特性を評価し, そ の温度依存性とひずみ速度依存性を検討する。また，こ の粘弾粘塑性特性の評価結果の妥当性を示すため, 粘弾 粘塑性体の数值解析アルゴリズムを構築し, 有限要素解 析を用いて単軸引張試験における力学挙動を再現する.

\section{2. 粘弾粘塑性構成モデル}

\section{1 粘弾粘塑性直列モデル}

本研究では, 線形粘弾性体と粘塑性体の組み合わせに よって熱可塑性樹脂の粘弾粘塑性挙動を表現する。ただ し, 線形粘弾性体は全ての非線形粘弾性材料定数を 1 としたSchapery 非線形粘弾性体で表せることから， Schapery 非線形粘弾性体と Perzyna 粘塑性体の直列モ デルにより熱可塑性樹脂の粘弾粘塑性挙動を表現する. ひずみが小さい場合，全ひずみが粘弾性成分と粘塑性成
分に分離できると仮定すると, 全ひずみテンソル $\varepsilon^{\text {total }}$ は 次式で表される.

$$
\varepsilon^{\text {total }}=\varepsilon^{\mathrm{ve}}+\varepsilon^{\mathrm{vp}}
$$

ここで， $\varepsilon^{\mathrm{ve}}$ は粘弾性ひずみテンソル， $\varepsilon^{\mathrm{vp}}$ は粘塑性ひず みテンソルである. また, 直列モデルでは, 粘弾性要素 と粘塑性要素に加わる応力は等しい.この直列モデルの 場合, 初期降伏応力以下では, $\boldsymbol{\varepsilon}^{\mathrm{vp}}=0$ すなわち純粋な粘 弾性挙動を示す.

三次元問題に拡張された等方性 Schapery 非線形粘弾 性構成式は, 粘弾性ひずみ履歴と Cauchy 応力テンソル $\boldsymbol{\sigma}(t)$ を関係づけた次式に示す Boltzmann 積分形で表さ れる ${ }^{16)}$.

$$
\boldsymbol{\varepsilon}^{\mathrm{ve}}(t)=g_{0} \mathbb{C}_{0}: \boldsymbol{\sigma}(t)+g_{1} \int_{0}^{t} \Delta \mathbb{C}\left(\psi-\psi^{\prime}\right): \frac{d\left(g_{2}^{\prime} \boldsymbol{\sigma}^{\prime}\right)}{d \boldsymbol{\xi}} d \xi
$$

ここで， $\mathbb{C}_{0}$ は 4 階の瞬間コンプライアンスマトリクス， $\Delta \mathbb{C}(t)$ は 4 階の過渡コンプライアンスマトリクスであ る. $\mathbb{C}_{0}$ と $\Delta \mathbb{C}(t)$ の各成分は, 時間に依存しないポアソン 比と, 次式に示す線形粘弾性クリープコンプライアンス $D(t)$ の Prony 級数で表される.

$$
\begin{gathered}
D(t)=D_{0}+\Delta D(t) \\
\Delta D(t)=\sum_{t=1}^{N} D_{i}\left\{1-\exp \left(-\frac{t}{\tau_{i}}\right)\right\}
\end{gathered}
$$

ここで， $D_{0}$ は瞬間クリープコンプライアンス， $\Delta D(t)$ は過渡クリープコンプライアンス, $D_{i}$ おょび $\tau_{i}$ は Prony 級数における各項の係数および遅延時間である. また，式(2)に拈いて， $g_{0}$ は瞬間クリープコンプライア ンス, $g_{1}$ は過渡クリープコンプライアンス, $g_{2}$ は負荷速 度の非線形性を表す非線形粘弾性材料定数である. 緩和 時間 $\psi(t)$ は次式で与えられる。

$$
\psi(t)=\int_{0}^{t} \frac{1}{\alpha_{T} \alpha_{\sigma}} d \eta
$$

ここで， $\alpha_{T}$ は時間-温度シフトファクター， $\alpha_{\sigma}$ は時間応力シフトファクターである.

粘塑性構成式は, 粘塑性ひずみ速度テンソル $\dot{\varepsilon}^{\mathrm{vp}}$ に関 する標準的な関連流れ則により

$$
\dot{\boldsymbol{\varepsilon}}^{\mathrm{vp}}=\dot{\gamma} \frac{\partial F\left(\boldsymbol{\sigma}, \bar{\varepsilon}^{\mathrm{vp}}\right)}{\partial \boldsymbol{\sigma}}
$$

で定義される.ここで, $\dot{\gamma}$ は粘塑性乗数であり, Perzyna 粘塑性では次式で表される。

$$
\dot{\gamma}=\frac{1}{\Gamma}\left(\frac{F\left(\boldsymbol{\sigma}, \bar{\varepsilon}^{\mathrm{vp}}\right)}{\sigma_{y}^{0}}\right)^{\varkappa}
$$

ここで， $\Gamma ， \varkappa$ は Perzyna 粘塑性の材料定数であり，そ 
れぞれ粘性パラメータと速度感度である。また，〈・は Macaulay 括弧である. 降伏関数 $F\left(\boldsymbol{\sigma}, \bar{\varepsilon}^{\mathrm{vp}}\right)$ は, 線形硬 化則を用いて次式で表される。

$$
F\left(\boldsymbol{\sigma}, \bar{\varepsilon}^{\mathrm{vp}}\right)=q(\boldsymbol{\sigma})-\sigma_{y}^{0}-h \bar{\varepsilon}^{\mathrm{vp}}
$$

式(7)において $\sigma_{y}^{0}$ は初期降伏応力, $h$ は硬化パラメータ である.また, $q(\boldsymbol{\sigma})$ は Mises の相当応力, $\bar{\varepsilon}^{\mathrm{vp}}$ は相当粘 塑性ひずみである。

\section{2 数值解析アルゴリズム}

ここでは, 既知の時刻 $t_{(n)}$ における各種ひずみテンソ ル $\boldsymbol{\varepsilon}_{(n)}^{\mathrm{total}}, \boldsymbol{\varepsilon}_{(n)}^{\mathrm{ve}}, \boldsymbol{\varepsilon}_{(n)}^{\mathrm{vp}}$, Cauchy 応力テンソル $\boldsymbol{\sigma}_{(n)}$, 履歴積 分項 $\boldsymbol{q}_{i(n)}$, 非線形粘弾性材料定数 $g_{0(n)}, g_{1(n)}, g_{2(n)}, \alpha_{\sigma(n)}$, 緩和時間増分 $\Delta \psi_{(n)}$, 相当粘塑性ひずみ $\bar{\varepsilon}_{(n)}^{\mathrm{vp}}$ と全ひずみ 増分テンソル $\Delta \boldsymbol{\varepsilon}^{\text {total }}$ から, 時刻 $t_{(n+1)}$ における Cauchy 応力テンソル $\boldsymbol{\sigma}_{(n+1)}$ とコンシステント接線係数を導くこ とを目的とする. 最初に, 後退 Euler 法による $\Delta t=$ $t_{(n+1)}-t_{(n)}$ 間での離散化構成式を示す. 次に, 粘弾粘塑 性直列モデルの数值解析アルゴリズムを示す.

Schapery 非線形粘弾性の離散化構成式は, 式(2)を離 散化した後に式(3)を代入することで

$$
\begin{aligned}
\Delta \boldsymbol{\varepsilon}^{\mathrm{ve}}= & \left(\overline{\mathbb{C}}_{(n+1)}: \boldsymbol{\sigma}_{(n+1)}-\overline{\mathbb{C}}_{(n)}: \boldsymbol{\sigma}_{(n)}\right) \\
& -\sum_{i=1}^{N} \mathbb{C}_{i}: \boldsymbol{q}_{i(n)}\left\{g_{1(n+1)} \exp \left(\frac{-\Delta \psi_{(n+1)}}{\tau_{i}}\right)-g_{1(n)}\right\} \\
& -g_{2(n)} \sum_{i=1}^{N} \mathbb{C}_{i}: \boldsymbol{\sigma}_{(n)}\left[g_{1(n)} \frac{\tau_{i}}{\Delta \psi_{(n)}}\left\{1-\exp \left(\frac{-\Delta \psi_{(n)}}{\tau_{i}}\right)\right\}\right. \\
& \left.-g_{1(n+1)} \frac{\tau_{i}}{\Delta \psi_{(n+1)}}\left\{1-\exp \left(\frac{-\Delta \psi_{(n+1)}}{\tau_{i}}\right)\right\}\right] \\
\overline{\mathbb{C}}_{(n+1)}= & g_{0(n+1)} \mathbb{C}_{0}+g_{1(n+1)} g_{2(n+1)} \sum_{i=1}^{N} \mathbb{C}_{i} \\
& \times\left[1-\frac{\tau_{i}}{\Delta \psi_{(n+1)}}\left\{1-\exp \left(\frac{-\Delta \psi_{(n+1)}}{\tau_{i}}\right)\right\}\right] \\
\Delta \boldsymbol{q}_{i}=\{ & \left.1-\exp \left(\frac{-\Delta \psi_{(n+1)}}{\tau_{i}}\right)\right\} \\
& \times\left[\frac{\tau_{i}}{\Delta \psi_{(n+1)}}\left\{g_{2(n+1)} \boldsymbol{\sigma}_{(n+1)}-g_{2(n)} \boldsymbol{\sigma}_{(n)}\right\}-\boldsymbol{q}_{i(n)}\right]
\end{aligned}
$$

と表される ${ }^{17)}$.ここで, 式(4)の離散化関係は有限差分法 による解とした ${ }^{18)}$.

また, 式(5)から式(7)より関連流れ則と Perzyna 粘塑 性, 降伏関数の離散化構成式は

$$
\begin{aligned}
& \Delta \varepsilon^{\mathrm{vp}}=\Delta \gamma \frac{\partial F\left(\boldsymbol{\sigma}_{(n+1)}, \bar{\varepsilon}_{(n+1)}^{\mathrm{vp}}\right)}{\partial \boldsymbol{\sigma}_{(n+1)}} \\
& \Delta \gamma=\frac{\Delta t}{\Gamma}\left\langle\frac{F\left(\boldsymbol{\sigma}_{(n+1)}, \bar{\varepsilon}_{(n+1)}^{\mathrm{vp}}\right)}{\sigma_{y}^{0}}\right\rangle^{k}
\end{aligned}
$$

$$
F\left(\boldsymbol{\sigma}_{(n+1)}, \bar{\varepsilon}_{(n+1)}^{\mathrm{vp}}\right)=q\left(\boldsymbol{\sigma}_{(n+1)}\right)-\sigma_{y}^{0}-h \bar{\varepsilon}_{(n+1)}^{\mathrm{vp}}
$$

と表される7).

式(8) から式(11)より粘弾粘塑性直列モデルは, 応力テ ンソル $\boldsymbol{\sigma}_{(n+1)}$ と粘塑性乗数 $\Delta \gamma$ に関する非線形式である ことが分かる.したがって, これらの未知数を求める数 值解析アルゴリズムが必要となる. 本研究では, Wang らが提案した consistency モデルを用いて数值解析のア ルゴリズムを構築する ${ }^{19)}$.このアルゴリズムモデルでは, 動的降伏曲面を導入することで粘塑性整合条件式を古典 的な速度非依存塑性と同様に定義することができる. 式 （10）および式(11)より動的降伏曲面 $\chi$ が次式で表せる.

$$
\chi=\left[q\left(\boldsymbol{\sigma}_{(n+1)}\right)-\sigma_{y}^{0}-h \bar{\varepsilon}_{(n+1)}^{\mathrm{vp}}\right]-\sigma_{y}^{0}\left(\Gamma \frac{\Delta \gamma}{\Delta t}\right)^{\frac{1}{k}}
$$

式(12)において，右辺第 1 項の降伏関数と右辺第 2 項の Perzyna 粘塑性の降伏曲面は常に等しい. したがって, $\chi \approx 0$ を満たす粘塑性乗数 $\Delta \gamma$ を Newton-Raphson 法で 求めることができる. しかし, 応力テンソル $\boldsymbol{\sigma}_{(n+1)}$ が未 知であるため, 応力増分テンソル $\Delta \boldsymbol{\sigma}$ も同様に非線形解 法で決定する必要がある ${ }^{20)}$ そこで，残差ひずみ増分テ ンソル $\boldsymbol{R}_{\Delta \varepsilon}$ を次式で定義する.

$$
\boldsymbol{R}_{\Delta \varepsilon}=\Delta \boldsymbol{\varepsilon}^{\mathrm{ve}}+\Delta \boldsymbol{\varepsilon}^{\mathrm{vp}}-\Delta \boldsymbol{\varepsilon}^{\mathrm{total}}
$$

ここで， $\Delta \boldsymbol{\varepsilon}^{\mathrm{ve}}$ は式(8)， $\Delta \boldsymbol{\varepsilon}^{\mathrm{vp}}$ は式(9)で定義され， $\Delta \boldsymbol{\varepsilon}^{\text {total }}$ は既知の全ひずみ増分テンソルである. 残差ひずみテン ソル $\boldsymbol{R}_{\Delta \varepsilon}$ の各成分は常に 0 であることから, $\left\|\boldsymbol{R}_{\Delta \varepsilon}\right\| \approx 0$ を 満たす応力増分テンソル $\Delta \boldsymbol{\sigma}$ を Newton-Raphson 法で 求めることができる. 以上より, この数值解析アルゴリ ズムでは, 応力増分テンソル $\Delta \sigma$ の試行值に対し粘塑性 乗数 $\Delta \gamma$ を決定する手順を繰り返すことで解を導く.こ の数值解析アルゴリズムの有限要素法への実装は, Abaqus/Standard user-material subroutine UMATにより 行う.

\section{3. 材料試験方 法}

\section{1 動的粘弾性試験}

本研究では板厚 $3.1 \mathrm{~mm}$ の ASTM D631 に準拠した標 準引張試験片に射出成形されたポリブチレンテレフタレ ート（PBT）樹脂を用いる。動的粘弾性試験（DMA 試 験)では, 標準引張試験片の平行部から幅 $6 \mathrm{~mm}$, 厚さ 1 $\mathrm{mm}$, 長さ $20 \mathrm{~mm}$ に切り出した試験片を用いる. 測定周 波数は $1 \mathrm{~Hz}, 2 \mathrm{~Hz}, 10 \mathrm{~Hz}$ の 3 条件とし, 昇温速度 $2^{\circ} \mathrm{C} /$ $\min$ でー $100^{\circ} \mathrm{C}$ か $200^{\circ} \mathrm{C}$ で温度を上昇させながら実 施する. 負荷モードは引張り, 平均ひずみは約 $1 \%, ひ$ 
ずみ振幅は約 $0.1 \%$ である.

DMA 試験で計測された貯蔵弾性係数 $E^{\prime}(\omega)$ と損失 弾性係数 $E^{\prime \prime}(\omega)$ から応力緩和係数 $E_{\gamma}(t)$ を求めるため には，二宮と Ferry が提案した次式を用いる ${ }^{21)}$.

$$
E_{\gamma}(t)=E^{\prime}(\omega)-0.4 E^{\prime \prime}(0.4 \omega)+0.014 E^{\prime \prime}(10 \omega)
$$

ここで, $=1 / t$ である. また, 応力緩和係数からクリー プコンプライアンスを求めるためには, 実時間面におい て応力緩和係数 $E_{\gamma}(t)$ の Prony 級数の係数からクリー プコンプライアンスの Prony 級数の係数を求める ParkSchapery 法を用いる ${ }^{22)}$.

\section{2 単軸引張試験}

単軸引張試験には, 最大荷重 $10 \mathrm{kN}$ の卓上型引張試験 機を使用し，荷重はロードセルで計測する。ひずみは試 験片に白と黒のスプレーでランダムパターンを作成し, CCD カメラで撮影した画像からデジタル画像相関法 (DIC) で計測する.試験片は射出成形された板厚 $3.1 \mathrm{~mm}$ の標準引張試験片である. 異なる温度における力学挙動 を計測するため, 全条件の試験を恒温槽内で行う.ク口 スヘッド速度は $0.1 \mathrm{~mm} / \mathrm{min}, 1 \mathrm{~mm} / \mathrm{min}, 10 \mathrm{~mm} / \mathrm{min}$ の 3 条件, 温度は $15^{\circ} \mathrm{C}, 25^{\circ} \mathrm{C}, 40^{\circ} \mathrm{C}, 50^{\circ} \mathrm{C}, 60^{\circ} \mathrm{C}$ の 条 件である. DICでは, 標準試験片の平行部中央の 7.2 $\mathrm{mm} \times 7.2 \mathrm{~mm}$ の測定範囲の平均ひずみを計測する。ま た, クロスヘッド速度に応じて計測時間間隔を変更し, 相関が取れるひずみ範囲内で行う。

\section{4. 試験結果と粘弾粘塑性特性評価}

\section{1 粘弾性特性}

Fig. 1 に時間-温度換算則によって得られた基準温度 $25^{\circ} \mathrm{C}$ における応力緩和係数のマスターカーブの一部とそ の Prony 級数近似曲線, Park-Schapery 法で求めたク リープコンプライアンスの Prony 級数近似曲線を示す. また, Fig. 2 に時間-温度シフトファクターを示す. 本研 究のDMA では連続的に温度を上昇させながら測定し

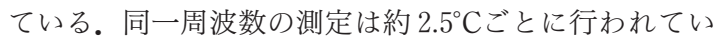
るが，3つの周波数における測定は異なる温度で行われ ている.そのため, マスターカーブ作成の際には, Fig. 2 に示す関数の值に基づいて各周波数の粘弾性物性值を時 間軸方向に移動させた。また，滑らかなマスターカーブ を得るためにシフトファクターには不連続な関数を使用 した.

DMA 試験における応答応力は, 低温側が約 $1.6 \mathrm{MPa}$, 高温側が約 $0.3 \mathrm{MPa}$ と低い. したがって, DMA 試験よ り得られた粘弾性特性は線形粘弾性であると考えられ

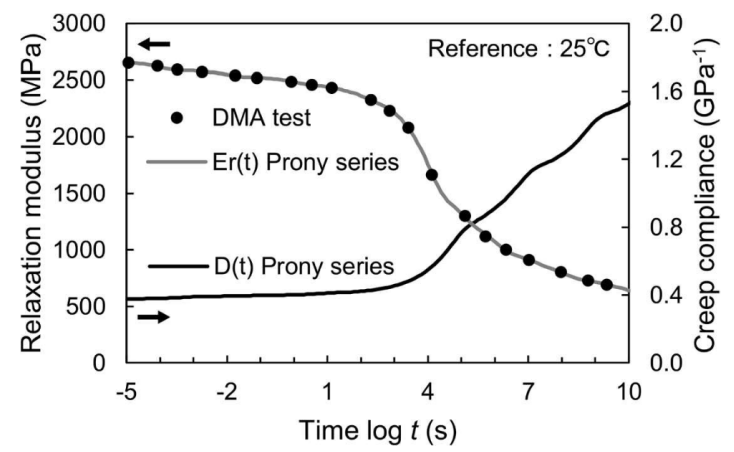

Fig. 1 Master curve of relaxation modulus evaluated by dynamic mechanical analysis and approximated curves by Prony series.

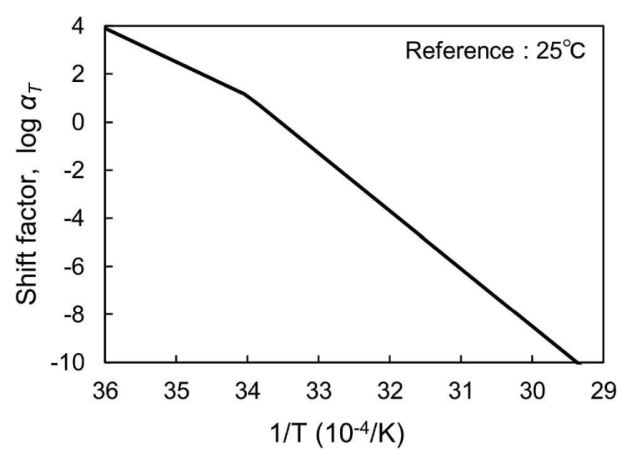

Fig. 2 Shift factor for the master curve of the relaxation modulus obtained by dynamic mechanical analysis.

る. 本研究では, 粘弾性特性として Fig. 1 に示すクリー プコンプライアンスを用いる. ポアソン比は 0.35 とする. また, 降伏応力以下において純粋な線形粘弾性挙動を示 すと仮定し, 非線形粘弾性材料定数 $\left(g_{0}, g_{1}, g_{2}, \alpha_{\sigma}\right)$ を 1 とする. 基準温度 $25^{\circ} \mathrm{C}$ 以外の任意温度におけるクリー プコンプライアンスは, Fig. 2 に示すシフトファクター を用いた時間-温度換算則により得る.

\section{2 粘塑性特性}

Fig. 3 に単軸引張試験から得た真応力-真ひずみ関係 をプロットで示す.Fig. 3 (a)，（b)，（c）はそれぞれクロ スヘッド変位速度 $0.1 \mathrm{~mm} / \mathrm{min}, 1 \mathrm{~mm} / \mathrm{min}, 10 \mathrm{~mm} / \mathrm{min}$

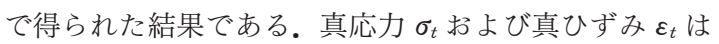
以下の算出式で計算した。

$$
\begin{aligned}
\sigma_{t} & =\sigma_{n}\left(1+\varepsilon_{n}\right) \\
\varepsilon_{t} & =\ln \left(1+\varepsilon_{n}\right)
\end{aligned}
$$



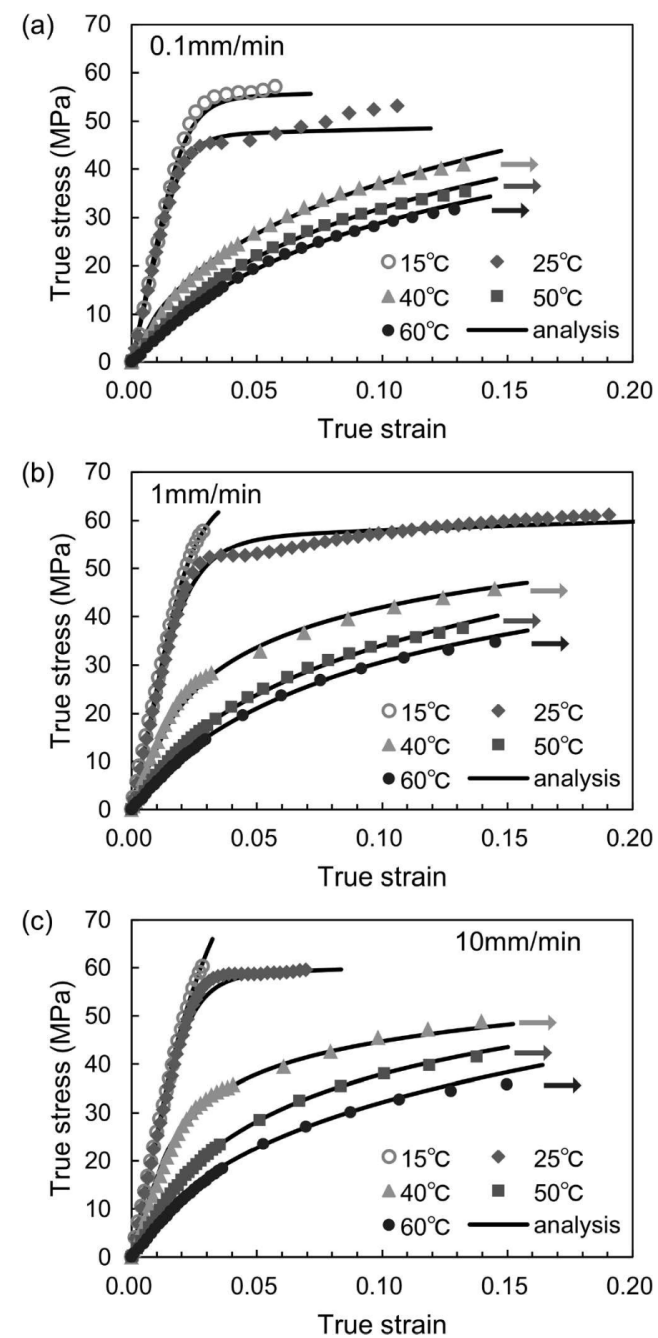

Fig. 3 True stress-true strain curves obtained by tensile tests and viscoelastic-viscoplastic analyses at various temperatures and a cross-head displacement speed of (a) 0.1 $\mathrm{mm} / \mathrm{min}$, (b) $1 \mathrm{~mm} / \mathrm{min}$ and (c) $10 \mathrm{~mm} /$ $\min$.

ここで， $\sigma_{n}$ は試験片の初期断面積とロードセルで計測し た荷重值から求まる公称応力, $\varepsilon_{n}$ は DICで計測される 公称ひずみである.Fig. 3 より, 顕著な温度依存性があ ることが分かる. 加えて, 同じ温度条件でもひずみ速度 で異なる挙動を示していることがわかる．また， $40^{\circ} \mathrm{CW}$ 上の全てのクロスヘッド速度条件においてネッキング現 象が生じた。このネッキング現象が生じた場合, DICに よるひずみ計測は困難となる。したがって, Fig. 3 では,

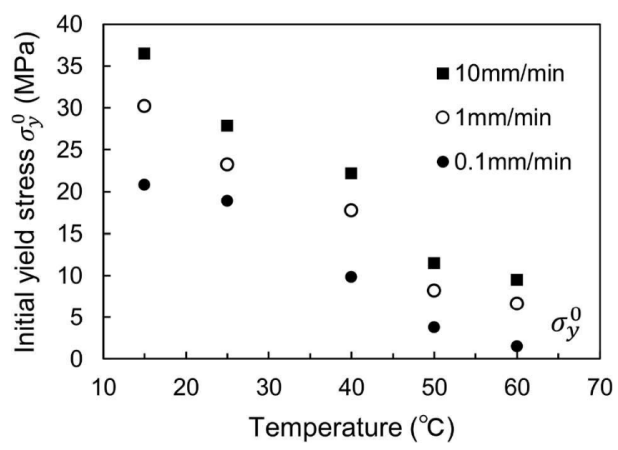

Fig. 4 Relationship between initial yield stress and temperature.

$25^{\circ} \mathrm{C}$ の $10 \mathrm{~mm} / \mathrm{min}$ と $40^{\circ} \mathrm{C}$ 以上の全てのクロスヘッド速 度条件において，DIC によるひずみ計測ができた範囲ま でがプロットされている，その他の条件では，破断まで の真応力-真ひずみ関係がプロットされている.

単軸引張試験結果から粘塑性材料定数を求めるために は，全ひずみから粘弾性ひずみと粘塑性ひずみを分離す る必要がある. 粘弾粘塑性直列モデルでは, 粘弾性要素 と粘塑性要素に加わる応力が等しい. そのため, 単軸引 張試験で得た応力の時間履歴 $\sigma(t)$ と DMA 試験で得た 線形粘弾性クリープコンプライアンス $D(t)$ から粘弾性 ひずみ履歴 $\varepsilon^{\mathrm{ve}}(t)$ が推定できる.したがって, 式(1)の直 列モデルにおけるひずみ成分の関係より, 計測された全 ひずみ履歴 $\varepsilon^{\text {total }}(t)$ から推定された粘弾性ひずみ履歴 $\varepsilon^{\mathrm{ve}}(t)$ を引くことで粘塑性ひずみ履歴 $\varepsilon^{\mathrm{vp}}(t)$ を推定する ことができる.また, 式(5)に示す標準的な関連流れ則よ り, 単軸の場合 $\dot{\varepsilon}^{\mathrm{vp}}=\dot{\gamma}$ が成り立つことが分かる.このこ とから,推定した粘塑性ひずみ履歴 $\varepsilon^{\mathrm{vp}}(t)$ と式(6)の差を 最小にする 3 つの粘塑性材料定数 (初期降伏応力 $\sigma_{y}^{0}$, 粘 性パラメータ $\Gamma$, 速度感度 $\varkappa$ ）を最小二乗法で決定する。 ここで，ひずみ硬化やひずみ軟化は生じないと仮定し， 硬化パラメータ $h$ は全条件で $h=0$ とする.

Fig. 4 に初期降伏応力 $\sigma_{y}^{0}$, Fig. 5 に粘性パラメー夕 $\Gamma$, Fig. 6 に速度感度 $\varkappa$ の評価結果を示す. Fig. 4 の初 期降伏応力は, 温度が上昇するにともない低下している. また，ひずみ速度が速くなるにともない上昇している。 この傾向は, 最大応力の温度依存性やひずみ速度依存性 と同様である。

Fig. 5 は粘性パラメータとひずみ速度 $\dot{\varepsilon}$ の逆数の両対 数関係を示している. Fig. 5 より，ひずみ速度が遅くな ると粘性パラメータが大きくなっており，顕著なひずみ 速度依存性を示すことが分かる。また，粘性パラメータ 


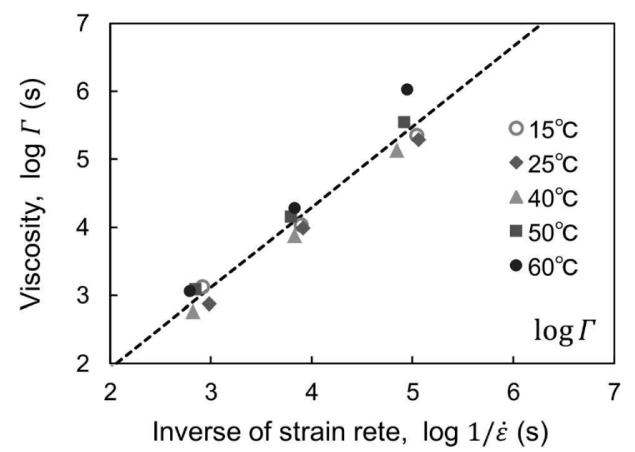

Fig. 5 Relationship between viscosity and inverse of strain rate.

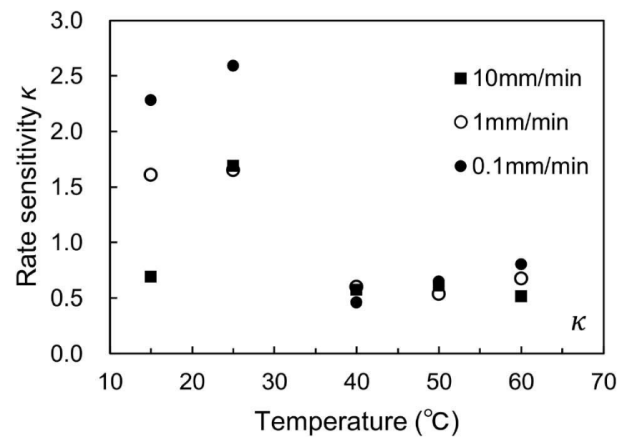

Fig. 6 Relationship between rate sensitivity and temperature.

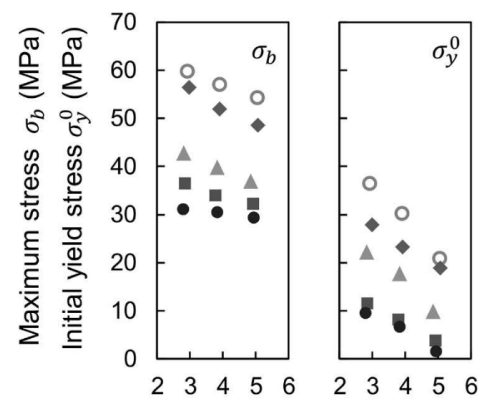

Inverse of strain rate, $\log 1 / \dot{\varepsilon}(\mathrm{s})$

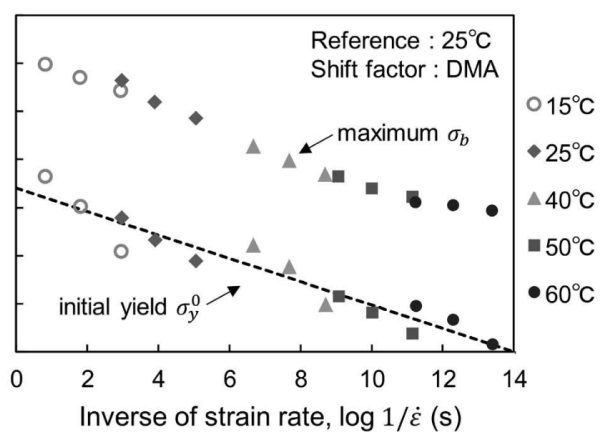

Fig. 7 Master curve of maximum nominal stress and initial yield stress using shift factor determined by dynamic mechanical analysis.

はひずみ速度に関係していることが分かる，これは，式 (6)よりひずみ硬化や軟化が生じない仮定では，粘性パ ラメータが粘塑性ひずみ速度に依存するためである。し たがって, 硬化パラメータ $h=0$ の場合, ひずみ速度か ら粘性パラメー夕を推定できる。また，粘性パラメー夕 の温度依存性はみられない。

Fig. 6 の速度感度は，ひずみ速度に関係なく $40^{\circ} \mathrm{C}$, $50^{\circ} \mathrm{C}, 60^{\circ} \mathrm{C}$ の同定結果が $\varkappa=0.5$ 付近でほぼ等しい結果 となった。しかし, $15^{\circ} \mathrm{C}$ と $25^{\circ} \mathrm{C}$ 值はひずみ速度ごとの ばらつきが大きく, ひずみ速度依存性および温度依存性 は明らかでないことが分かる。

\section{5. 有限要素法による粘弾粘塑性解析}

評価した材料定数を用いて，有限要素法による粘弾粘 塑性解析を行った。解析ソフトはAbaqus/Standard 2017 を使用し, 解析モデルは標準型試験片の平行部をモ デル化した高さ $57.6 \mathrm{~mm}$ ，幅 $12.8 \mathrm{~mm}$ ，厚さ $3.1 \mathrm{~mm}$ の 直方体とする。また，要素タイプは 8 節点連続体 6 面体 要素, 要素サイズは $1.6 \mathrm{~mm} \times 1.6 \mathrm{~mm} \times 1.55 \mathrm{~mm}$, 要素数
は 576 である. Fig. 3 に粘弾粘塑性解析から得た真応力一 真ひずみ関係を示す.この図では, プロットが実験結果， 実線が解析結果を示している，全てのひずみ速度と温度 条件で実験と解析がほぼ一致する結果を得られた。した がって, Schapery 非線形粘弾性体と Perzyna 粘塑性体 の直列モデルに基づく粘弾粘塑性特性の評価結果は妥当 であると言える。

\section{6. 最大応力と初期降伏応力の時間-温度依存性}

Fig. 7 亿最大公称応力 $\sigma_{b}$ と初期降伏応力 $\sigma_{y}^{0}$ のマス夕 一カーブを示す. 縦軸の最大公称応力 $\sigma_{b}$ は, 単軸引張試 験の公称応力-伸び線図から得た值である.横軸はひず

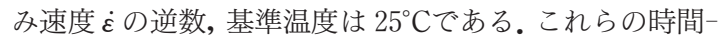
温度シフトファクターは, Fig. 2 亿示す DMA 試験で取 得した值を使用した. Fig. 7 より, 最大応力のマスター カーブは滑らかな曲線を描いていることが分かる。した がって, 最大応力の時間-温度換算則は成立していると 言える.この結果は, 既存の研究と同様である ${ }^{12)}$.

一方，初期降伏応力についても破線で示す回帰直線に 
着目すると，一本のマスターカーブが存在していると考 えられる. しかし, 回帰直線上で異なる温度条件の初期 降伏応力はわずかにずれている.この理由として, Fig. 4 に示した初期降伏応力は, PBT 樹脂の実際の初期降伏 応力と異なる可能性が考えられる。

本研究では, Schapery 非線形粘弾性において $g_{0}=$ $g_{1}=g_{2}=\alpha_{\sigma}=1$, つまり理想的な線形粘弾性挙動を仮定 した。しかし, 実際の PBT 樹脂はクリープ試験におい て応力依存の非線形粘弾性を発現する。非線形粘弾性が ある場合, 線形粘弾性に比べてクリープコンプライアン スが大きくなるため, 推定される粘弾性ひずみは増加す る. 推定粘弾性ひずみが増加すると, Fig. 3 の応力ーひず み関係において粘弾性ひずみ域が広がり, 初期降伏応力 が上昇する。したがって, 非線形粘弾性を示す PBT 樹 脂の実際の初期降伏応力は, Fig. 4 亿示した初期降伏応 力よりも全体的に大きくなると考えられる。 また，非線 形粘弾性のクリープコンプライアンスと線形粘弾性クリ ープコンプライアンスの差は, 時間の経過にともない大 きくなる，そのため，ひずみ速度が遅いほど推定される 粘弾性ひずみが大きくなり, 初期降伏応力の上昇量は大 きくなると考えられる.

以上より, 非線形粘弾性を考慮した場合, 初期降伏応 力は全体的に上昇し, その上昇量はひずみ速度が遅い条 件ほど大きいと推測される。この場合, 初期降伏応力の マスターカーブはより滑らかな曲線で表現できると考え られる。しかし, Schapery 非線形粘弾性特性の計測に は, 異なる応力条件下のクリープリカバリー試験が必要 である。そのため, 非線形粘弾性を考慮した検討は今後 の課題である.

\section{7. 結言}

熱可塑性樹脂の粘弾粘塑性挙動を Schapery 非線形粘 弾性体と Perzyna 粘塑性体でモデル化した. 動的粘弾 性試験から得た粘弾性特性を用いて粘塑性ひずみを推定 し, 粘塑性特性を評価した。 その結果, 初期降伏応力, 粘性パラメー夕, 速度感度の温度とひずみ速度の依存性 を明らかにした。評価した粘弾粘塑性特性を用いた有限 要素解析では, 全ての条件で熱可塑性樹脂の力学挙動が 再現可能であることから, 粘弾粘塑性特性の評価結果は 妥当である.

\section{参 考 文 献}

1) R. Schapery : Int. J. Solids Struct., 2, 3 (1966), 407425.

2) R. Schapery: Polym. Eng. Sci., 9, 4 (1969), 295-310.

3) J. Chaboche: Int. J. Plasticity, 24, 10 (2008), 16421693.

4) P. Perzyna: Adv. Appl. Mech., 9, C (1966), 243-377.

5) P. Perzyna: Adv. Appl. Mech., 11, C (1971), 313-354.

6) E. De Souza Neto, D. Perić \& D. Owen : Computational Methods for Plasticity: Theory and Applications (1st Ed.), Civil and Computational Engineering Centre (2008).

7) J. Kim \& A. Muliana : Int. J. Num. Meth. Eng., 79, 5 (2009), 550-575.

8) J. Kim \& A. Muliana : Int. J. Solids Struct., 47, 1 (2010), 580-594.

9) D. Tscharnuter, M. Jerabek, Z. Major \& G. Pinter : Mech. Time-Depend. Mater., 16, 3 (2012), 275-286.

10) R. Abu Al-Rub, A. Tehrani \& M. Darabi : Int. J. Damage Mech., 24, 2 (2014), 198-244.

11) A.H. Tehrani \& R. Abu Al-Rub : J. Eng. Mater. Technol., 133, 4 (2011), 041011.

12) A.D. Drozdov: Mech. Time-Depend. Mater., 14, 4 (2010), 411-434.

13) S. Zaoutsos, G. Papanicolaou \& A. Cardon: Compos. Sci. Technol., 58, 6 (1998), 883-889.

14) G. Papanicolaou, S. Zaoutsos \& A. Cardon : Composites Part A, 30, 7 (1999), 839-848.

15) G. Papanicolaou, S. Zaoutsos \& A. Cardon : Compos. Sci. Technol., 59, 9 (1999), 1311-1319.

16) J. Lai \& A. Bakker: Polym. Eng. Sci., 35, 17 (1995), 1339-1347.

17) R. Haj-Ali \& A. Muliana : Int. J. Num. Meth. Eng., 59, 1 (2004), 24-45.

18) T. Crochon, T. Schönherr, C. Li \& M. Lévesque : Mech. Time-Depend. Mater., 14, 4 (2010), 359-387.

19) W. Wang, L. Sluys \& R. De Borst: Int. J. Num. Meth. Eng., 40, 20 (1997), 3839-3864.

20) C. Huang, R. Abu Al-Rub, E. Masad, D. Little \& G. Airey : Int. J. Pavement Eng., 12, 4 (2011), 433 -447 .

21) K. Ninomiya \& J. Ferry: J. Colloid Sci., 14, 1 (1959), 36-48.

22) S. Park \& R. Schapery : Int. J. Solids Struct., 36, 11 (1999), 1653-1675. 